\title{
Proceeding
}

Supplementary Issue: Rio 2016 Olympic Games Third Anniversary Special Edition. Olympic Studies Forum, 2-3 September

2019. Federal University of Sergipe, Aracaju, Brazil

\section{Innovation and technology in Olympic Studies Brazilian publications based on Olympic Agenda 2020}

\author{
ANA MARIA DE FREITAS-MIRAGAYA \\ University of Estácio de Sá, UNESA, Brazil
}

\begin{abstract}
Innovation refers to the application of ideas that are novel and useful, preceding product or technology in organizations and in management. The objective of this text is to celebrate a panorama of innovation and technology in the Olympic Studies area sharing publications developed in Brazil based on Olympic Agenda 2020, the ultimate Olympic innovation launched in 2014. From the very first steps of the Olympic Movement in France, highlighting the early Brazilian publications in the Olympic Studies area and reaching the second decade of the 21st century, this text unfolds how innovation and technology are applied to books and platforms inspired by Olympic Agenda 2020. The Brazilian production of collective international free e-books in the Olympic Studies area, following Recommendations of Olympic Agenda 2020, started a trend which has had great impact not only on education, but also on the significance of innovation and technology for the development of our civilization. Keywords: Innovation; Technology; Olympic Studies; Olympic Agenda 2020; Brazilian publications.
\end{abstract}

Cite this article as:

de Freitas-Miragaya, A.M. (2020). Innovation and technology in Olympic Studies Brazilian publications based on Olympic Agenda 2020. Journal of Human Sport and Exercise, 15(1proc), S23-S28. doi:https://doi.org/10.14198/ihse.2020.15.Proc1.03

Corresponding author. Rodovia BR040 Km 66 Casa 18. Condomínio Quinta do Lago. Araras Petrópolis, RJ. CEP: 25725-905. Brasil.

E-mail: ana.miragaya@estacio.br

Supplementary Issue: Rio 2016 Olympic Games Third Anniversary Special Edition. Olympic Studies Forum, 2-3 September 2019. Federal University of Sergipe, Aracaju, Brazil.

JOURNAL OF HUMAN SPORT \& EXERCISE ISSN 1988-5202

(c) Faculty of Education. University of Alicante

doi:10.14198/jhse.2020.15.Proc1.03 


\section{INTRODUCTION}

Innovation is a loaded word as it contains many meanings that change according to the area which they refer to, but all of them carry the expression 'novelty'. Innovation can be separated from creativity as the former refers to the application of ideas that are novel and useful while the latter represents the seed of innovation and continues to be only an idea if it is not applied to anything, according to Burkus (2017). In fact, innovation in organizations and in management precedes product or technology as it is the implementation of something new that can surprise clients, customers, stakeholders, and promote change. Innovation also helps face the challenges of today and those of tomorrow. In other words, what may have contributed to development and success in the past may not be of service in the present or in the future. In addition, innovation can mean keeping something relevant (Shapiro, 2011). If organizations do not develop and adapt to inevitable changes that happen due to the fast pacing world, they lose their importance and others take their place.

Taking these points into consideration, the objective of this text is to celebrate a panorama of innovation and technology in the Olympic Studies area sharing publications developed in Brazil based on Olympic Agenda 2020, the ultimate Olympic innovation launched in 2014.

\section{DEVELOPMENT}

\section{First steps}

The International Olympic Committee (IOC) was founded during the International Athletic Congress of Paris, on 23 June 1894, by Baron Pierre de Coubertin (1863-1937), symbol of innovation, and the first Olympic entrepreneur to establish international Olympic Games. He put into practice his idea by scheduling the first Olympics (Games of the Olympiad) of modern times to be celebrated in Athens, Greece, in 1896, after inviting Demetrius Vikela, Greek IOC member, as the first president of the IOC (1894-1896). With the revival of the Games, Coubertin, who was focused on and passionate about transforming the world and making it a better place through sport, also exposed the meaning of Modern Olympism, which, according to the Olympic Charter (2019), "is a philosophy of life, exalting and combining in a balanced whole the qualities of body, will and mind. Blending sport with culture and education, Olympism seeks to create a way of life based on the joy found in effort, the educational value of good example and respect for universal fundamental ethical principles" (Olympic Charter, 2019, pg. 11).

As time went by and into the $20^{\text {th }}$ century, the Olympic Movement had come to remodel its own structure in order to keep up with the changes society around the world was going through, such as, the new roles played by women, the importance given to sport in schools, education became a revolution in many nations, two World Wars, the recognition of professional sport, the development of sports federations, the creation of new sports, the development of new technologies that not only improved the world and Olympic records, but also made it possible for para-athletes to compete. In response to the many challenges, the Olympic Program came to include women athletes and professional athletes, increased the number of sports and athletes, added winter sports and youth games, rescued Olympic values, to finally come up with the highest innovation of all: Olympic Agenda 2020.

Facing new challenges and opening doors to technology and innovation, the Olympic Movement also added new features as it grew in size and in relevance: the International Olympic Academy (IOA) was created in 1948, in Greece, with National Olympic Academies inaugurated all around the world, the International Paralympic Committee (IPC) was established in 1989, and the International Pierre de Coubertin Committee 
(IPCC) was founded in 1974 in Switzerland, with national committees established in many countries, including Brazil.

The revival of the Olympic Games, its successful expansion and the prosperous development of the Olympic Movement established an essential field of study and research named Olympic Studies, which comprises a very broad area devoted to any theme related to the Olympic Movement, from philosophy and history to education and law. The scope of Olympic Studies grew in size and number of scholars, expanded into centres and research groups around the world. Located in different states, five research groups were founded in Brazil, developing projects, conducting studies and producing knowledge and innovation.

As first works, it is crucial to mention three outstanding publications in Brazil. The starting point of Olympic Studies was the book "Jogos Oympicos de Hontem, de Hoje e de Amanhan", written in 1937 by Americo Netto ("Olympic Games of Yesterday, of Today and of Tomorrow"), who described and analysed Pierre de Coubertin's ideas from the educational viewpoint, examining for the first time some possible applications in Brazil (DaCosta et al., 2017). The second one came up in 1969 in the collective volume: "XIX Olimpiada México 68 - Aspectos Técnicos Evolutivos" (The 19th Olympiad of Mexico 68 - Aspects of Technical Development). The texts focused both on the management of the Olympic Games and on Olympic sports. The third publication came up thirty years later: "Estudos Olímpicos" ("Olympic Studies"), another collective volume, edited by Tavares and DaCosta. It represented a cornerstone for the new developments of Olympic Studies and Olympic Education in Brazil. The text updated the readers on Olympic themes and exposed the tradition of authors related to the educational environment, displaying how the ideas which had been around Brazil since 1937 were adapted and improved along the years.

\section{Olympic Agenda 2020}

In spite of the great financial and public success the Olympic Games has enjoyed along the years, IOC President Thomas Bach, in his speech on December $7^{\text {th }}$ 2014, in Monaco, stated that "success is the best reason for change once the success of yesterday means nothing for today. The success of today gives you only the opportunity to drive the change for tomorrow" (Bach, 2014, p. 2). His speech launched Olympic Agenda 2020, whose main objective is to give a clear picture of where the Olympic Movement is heading and how the uniqueness of the Games can be protected, and Olympic values can be strengthened in society. It is indeed an innovation as it promotes changes and preserves the relevance of the Olympic Movement and the Olympic Games.

Olympic Agenda 2020 presents 40 detailed recommendations made by the IOC Executive Board after 14 IOC Working Groups discussed and worked on 1,200 ideas generated from 40,000 suggestions sent from the public in general, experts and stakeholders of the Olympic Movement. These recommendations are "like individual pieces of a jigsaw puzzle, which when put together give us a clear picture of what the future of the Olympic Movement will look like" (Bach, 2014, p.1).

Following the road on technology and innovation, paved by the 40 recommendations of Olympic Agenda 2020, the Olympic Studies Research Group based at the State University of Rio de Janeiro (GPEO UERJ), founded by professor Lamartine DaCosta, went on to produce three bilingual international academic e-books, free of charge and available on the internet.

\section{Books as innovation in Olympic Studies in Brazil based on Olympic Agenda 2020}

The pioneer publication, "The Future of Sports Megaevents" (Deslandes, DaCosta \& Miragaya, eds., 2015), represented quite an achievement not only in terms of novelty but also in terms of technology. For this reason, 
it was launched in May 2015 at the Rio de Janeiro House of Representatives. It was the very first collective international e-book, based on a platform, which touched upon many of the Recommendations of Olympic Agenda 2020, especially, Recommendation 20, directly related to virtual hub stakeholders. Olympic valuesbased education is an essential pillar of the Agenda (Recommendation 22) as it opens new doors to education, values, and technology to innovate and inspire the lead for a better world seen in chapters such as: "Review on Olympic and Paralympic Educational Values", by Abreu and Müller; "The Olympic Education Programs Acknowledged by the Brazilian Pierre de Coubertin Committee: a Stakeholder Model Taking Shape in Brazil", by Todt, and "Olympic Education as a Sustainable Innovation Development", by Turini, Gomes, DaCosta, Miragaya and Tavares.

Sustainability, another essential anchor of Olympic Agenda 2020, emphasized in Recommendations 4 and 5 ("include sustainability in all aspects of the Olympic Games" and "include sustainability within the Olympic Movement's daily operations"), also occupies part of the publication in chapters such as "Global City Meets Olympic Agenda 2020: toward a Unique and Sustainable Legacy?", by Tolzmann and "The Legacy Framework of Olympic Games", by Preuss.

Focus on athletes, according to Recommendations 17 and 18 ("honour clean athletes" and "strengthen support to athletes"), is highlighted in chapters such as "Innovation in the Relationships between Athlete, Training, and Sports Career in Institutions that Manage Paralympic Sports", by Haiachi and "The Clean Athlete and Olympic Agenda 2020", by Silva.

Recommendation 23 ("engage with communities: create a virtual hub for athletes, create a virtual hub of volunteers, engage with the general public, engage with youth") not only appeared in the virtual hub that gave origin to the book "The Future of Sports Megaevents" in chapters such as "Aims of the Platform-Book on Olympic and Paralympic Mega-events", by Deslandes and "Reconceptualization and Innovation Strategy for Volunteers of Sports Mega-events", by Pena, but also led to a more innovative and evolved e-publication, a virtual HubBook.

The second book, "New Cognitive and Virtual Interactions of Science of Sports and Olympic Studies", with the support of the Brazilian Pierre de Coubertin Committee, was launched during the Olympic Forum in Buenos Ayres, on the eve of the 2018 Summer Youth Olympic Games, and includes very recent technology. This bilingual non-commercial e-book facility, a product of creativity and innovation, is available on a free and open-source cloud computing platform in order to overcome the limitations of computing capability and storage capacity that are inherent in e-books and in many mobile devices. The hub service also allows users to build their own cloud systems in a public, private, and hybrid environment. It works as a digital platform offline and online with no commercial purposes and with free access to users, keeping the authors' rights, but allowing copies and the exposure of texts with the 17 authors' identities, the titles of the contributions and the acknowledgement of the source. The objective of this publication is to create an environment of innovation in the areas of Sciences and Technology of Sport and Olympic Studies based on the recommendations of Olympic Agenda 2020.

This Virtual Hub Book includes the STEM-based initiative, defined by UERJ for the National e-Sports Museum, thus identifying main interfaces of future operations with its stakeholders. As a result, the model CHAMEM (acronym elaborated from the expressions Collection, History, Archive, Memory, Exposition and Museum from Portuguese correspondent words) came into the development of the e-Museum's Project now searching updated technologies and meaningful innovations. 
Chapter 7, Sport History Related Modeling, for instance, includes "The Chamem Model Review", by DaCosta; "The National Museum of Sport", by Pena; "The Olympic Gallery", by Melo; "The National Archives", by Silva Junior and "Sport Heritage", by Tobar.

Chapter 8 displays sport hubs such as: the "Virtual Sports Center" (CEV), developed by Pereira; the "Olympic Studies Virtual Hub", elaborated by DaCosta and Miragaya; "FazGames", constructed by Turini, Zelter and Gomes; and "Mega-Event Footprints", organized by Mataruna and Pena.

With the focus on innovation and technology and still following Olympic Agenda 2020, DaCosta \& Miragaya did research on Brazilian aviator Santos-Dumont looking at Pierre de Coubertin's passion for sports and launched an inspiring and innovative volume. The initiative of the study, the research process and the destination of the text towards youth were concentrated on recommendations 18 ("strengthen support to athletes"), 20 ("Enter into strategic partnerships") 22 ("spread Olympic-values based education"), 23 ("engage with communities and engage with youth"), 26 ("blend sport and culture"), and 39 ("foster dialogue with society and within the Olympic Movement"). The first Brazilian Olympic hero was awarded one of the first Olympic diplomas by Coubertin in 1905, after the Baron himself had instituted the prize in 1901. The Baron described the Olympic Diploma by its meaning attributed to the awarded whose choices reveal "the rarity of the prize, not to reward such sporting victory, such record broken, such accomplished performance, which could be attributed to a man for his athletic qualities and above all the use he could have done" (DaCosta \& Miragaya, 2016, p. 86).

In the case of Santos-Dumont, the honour looked relevant because he was famous not only in France but also all over Europe by his prominent behaviour as a sportsman, typical of the pioneer aviators of the Belle Époque $^{3}$. During his adult life, confirming Coubertin's choice to indicate Santos-Dumont to receive the Olympic Diploma, the Brazilian pioneer exhibited himself as an explicit model of sportsman, daring and romantic, projecting his image of public personality in the city of Paris, which had become the world's centre for the arts, creation of fashion and lifestyles during the Belle Époque.

The book "Santos-Dumont, sport aviator: the first Olympic hero of Brazil" constitutes a revision of SantosDumont's historiography as an innovative sportsman of his time, reconstructing his lifetime history from original sources, focusing on an Olympic Santos-Dumont, assuming the sports environment as the basis for his inventions within the field of modern aeronautics, celebrating his innovation and the technology he himself developed.

Among the collaborative stakeholders, the volume on Santos-Dumont counted on institutions developed as outcomes of the innovation and leadership not only of Pierre de Coubertin (the International Pierre de Coubertin Committee - CIPC and the Brazilian Pierre de Coubertin Committee - CBPC), but also of SantosDumont (Brazilian Aeronautical Sports Commission - CDA, the Historic-Cultural Institute of Aeronautics INCAER, the Documentation Center of Brazilian Aeronautics - CENDOC, and the Brazilian Military Sport Commission - CBMB).

\section{CONCLUSION}

The same way Olympic Agenda 2020 addresses the relevance of the Olympic Movement and the Olympic Games, its innovation contributes not only to amaze and enchant stakeholders but also to advance change that will contest the challenges of today and of tomorrow. 
The Olympic Studies area, as an outcome of the greatest sport movement that started in the $19^{\text {th }}$ century, follows the same pathway, using technology and novelty to get adapted to a fast pacing society, which needs constant change. The work of scholars and researchers of this field becomes essential and relevant as they adjust their production of knowledge to meet the requisites of a global society using modern devices to contribute to world education and the spread of values.

The Brazilian production of collective international free e-books in the Olympic Studies area, following Recommendations of Olympic Agenda 2020, started a trend which has had great impact not only on education, but also on the significance of innovation and technology for the development of our civilization.

\section{REFERENCES}

Bach, T. (2014). Speech by IOC President Thomas Bach on the occasion of the Opening Ceremony, 127th IOC Session, Monaco, 7 December 2014. Lausanne: Olympic Agenda 2020.

Burkus, D. (2017). Under New Management. New York: Mariner Books.

DaCosta, L., Miragaya, A., Abreu, N., Tavares, O., Gomes, M. \& Turini, M. (2017). Brasil: Olympic Education in Brazil - experiences and trends. In R. Naul, D. Binder, A. Rychtecky \& I. Culpan (Eds) Olympic Education: An international review (pp. 89-103. New York: Routledge. https://doi.org/10.4324/9780203131510-12

DaCosta, L.P. (org.) (1969). XIX Olimpíada México 68 - Aspectos Técnicos Evolutivos" (The 19th Olympiad of Mexico 68 - Aspects of Technical Development) Brasília: Divisão de Educação FísicaMEC.

DaCosta, L. P. (org) \& Miragaya, A. (ed) (2018). New Cognitive and Virtual Interactions of Science of Sports and Olympic Studies. Petrópolis: Nova Studio.

DaCosta, L. P. \& Miragaya, A. (2016). Santos-Dumont, sport aviator: the first Olympic hero of Brazil. Rio de Janeiro: Engenho Arte e Cultura.

Deslandes, A., DaCosta, L. P. \& Miragaya, A. (eds) (2015). The Future of Sports Megaevents. Rio de Janeiro: Engenho Arte e Cultura.

IOC - International Olympic Committee (2014). Olympic Agenda 2020. 20+20 Recommendations. Retrieved from: https://goo.gl/6dWvPu

IOC - International Olympic Committee (2017). Olympic Charter, Retrieved from: https://goo.gl/BH5CYT

Netto, A. R. (1937). Jogos Oympicos de Hontem, de Hoje e de Amanhan ("Olympic Games of Yesterday, Today and Tomorrow"). São Paulo: Editora SPE.

Shapiro, S. (2011). Best Practices are Stupid: 40 Ways to Out-Innovate the Competition. New York: Portfolio.

Tavares, O. \& DaCosta, L.P. (eds) (1999). Estudos Olímpicos (Olympic Studies). Rio de Janeiro: Editora Gama Filho.

\section{(9) $(\Theta \Theta \Theta$}

This work is licensed under a Attribution-NonCommercial-NoDerivatives 4.0 International (CC BY-NC-ND 4.0). 